Marquette University

e-Publications@Marquette

Marketing Faculty Research and Publications

Marketing, Department of

4-1-1994

\title{
Towards 2000: A Tougher Future for Australian Business?
}

Gene R. Laczniak

Marquette University, eugene.laczniak@marquette.edu

Anthony Pecotich

Western Australia Institute of Technology

Angela Spadaccini

Western Australia Institute of Technology

Accepted version. Asia Pacific Journal of Management, Vol. 11, No. 1 (April 1994): 67-90. DOI. C) 1994 National University of Singapore, Faculty of Business Administration. Used with permission. 


\title{
Towards 2000: A tougher future for Australian business?
}

\author{
Gene R. Laczniak \\ Department of Marketing, Marquette University \\ Milwaukee, WI \\ Anthony Pecotich \\ Western Australia Institute of Technology, \\ Perth, WA Australia \\ Angela Spadaccini \\ Western Australia Institute of Technology, \\ Perth, WA Australia
}

\begin{abstract}
A study explores the future business environment expected by top level Australian executives. It forecasts environmental changes to the year 2000 and updates projections reported in an earlier study. Top managers from 171 of Australia's largest 500 corporations give their views concerning world ecology, the economy, technology, and political-social developments. Their perceptions are linked to specific competitive strategies that are evoked by the long-range forecast which they expect. A number of ecological trends are seen as likely to occur, including increased global pollution and increased levels of environmental regulation worldwide. There seems to be a general acceptance that the world will separate into regional alliances for the facilitation of world trade. Technological advancement in various forms is seen
\end{abstract}


NOT THE PUBLISHED VERSION; this is the author's final, peer-reviewed manuscript. The published version may be accessed by following the link in the citation at the bottom of the page.

as a potentially positive change agent. Certain sectors of the economy were ascribed a particularly high likelihood of substantial growth, including tourism and mining and processing of natural resources.

\section{Introduction}

About five years ago, a sample of 176 top level Australian managers predicted the state of the external business environment likely to be faced by Australian organisations by the mid 1990s (Laczniak et al, 1989). This follow-up study extends and improves upon that research by reporting the perceptions of 189 high level managers in terms of how they envisage the business environment unfolding to the year 2000. Before providing the details and results of this study, some preliminary comments about the role of environmental scanning in such forecasting efforts are provided.

\section{Environmental Scanning and Its Role in The Development of Competitive Strategy}

Environmental scanning can be defined as the seeking of information about events and relationships in a company's external environment; this knowledge assists top management in its task of charting the organisations's future course of action (Aguilar, 1967). Such an activity is critical to managers since one of their primary roles is to foresee and understand changes in the environments which affect their operations. This has been pointed out by various experts on numerous occasions (eg, Porter, 1980). However, the primary purpose of forecasting exercises like this is nor to obtain a highly accurate prediction. As Gareth Chang, President of McDonald-Douglas (Asia) operations stated, "trying to predict the future is necessary but impossible" (Fisher, 1990). Ultimately, the future is unknown. For example, the United States Defense Department employs a battery of planners and analysts who develop defense policy with an eye toward the future. Yet, they did not foresee recent major events such as the fall of the Berlin Wall and the subsequent transformation of Eastern Europe, the current political upheavals in China, or the disintegration of the former Soviet Union. If accurate prediction is not the point, then why should managers scan and forecast? The answer is that perceptions of future events, some of which will occur, become the basis upon which current strategic decisions are taken. In other words,

Asia Pacific Journal of Management, Vol 11, No. 1 (April 1994): pg. 67-90. DOI. This article is @ Springer and permission has been granted for this version to appear in e-Publications@Marquette. Springer does not grant permission for this article to be further copied/distributed or hosted elsewhere without the express permission from Springer. 
managers today take actions which are consistent with the future they expect tomorrow. In addition, such exercises make managers more sensitive and flexible to change.

There are a wide range of scanning techniques which might be used to forecast possible futures facing managers (Makridakis and Wheelwright, 1987). These methods range from highly quantitative (eg, time series analysis or causal models) to extremely qualitative (eg, the Delphi method). Because the purpose of this research was to gain a broad spectrum of opinion on a wide range of environmental issues relating to Australia in the year 2000, a qualitative judgmental forecasting technique was utilised. Specifically, Australian organisational elites were tapped as a jury of expert opinion on the supposition that such individuals would be in an excellent position to speculate about the dynamics of the changing environment which is facing business. Why? In their position as top managers, they are required to keep abreast of a variety of external developments and to bring their years of expertise to bear upon the interpretation of possible events as they might affect their industry and organisation. Previous studies on the forecasting techniques used by managers have shown that surveys of expert judgment and experience are commonly used in organisational decision making (Jain, 1984; Klein and Linneman, 1984).

\section{The Study Method}

Consistent with the rationale provided above, the respondents for this study consisted of top level managers in major Australian organisations. The sample was drawn from the directory Australia's Top 500 Companies--The Business Who's Who of Australia (1990). Two surveys were sent to each organisation, one addressed to the chief executive officer (CEO) and the other to the director of marketing. The objective of this procedure was to generate at least one completed survey from a knowledgeable organisational elite in each of these organisations. After one follow-up mailing, 171 different organisations had provided a completed questionnaire resulting in a response rate of $34 \%$. Given that the questionnaire was lengthy and administered to organisational elites with a reputation for not responding to such surveys--(due to company policy or because of the

Asia Pacific Journal of Management, Vol 11, No. 1 (April 1994): pg. 67-90. DOI. This article is C Springer and permission has been granted for this version to appear in e-Publications@Marquette. Springer does not grant permission for this article to be further copied/distributed or hosted elsewhere without the express permission from Springer. 
time demands upon such individuals), this response rate was felt to be quite good and comparable to other surveys (see discussion in Laczniak et al, 1989). The responding firms represented a wide crosssection of Australian industry: $28 \%$ were from the financial sector, $22 \%$ from mining and agriculture, $12 \%$ from insurance and property, $8 \%$ from high technology, and 5\% from the retail sector.

Response Bias. While a case can be made that sampling error is of little concern when using expert opinion because one does not necessarily have to procure all the experts in order to pool a meaningful amalgam of opinions, tests of non-response bias were performed for this survey. These calculations were done on a random sample of 30 responding companies as well as 30 organisations that did not respond. Organisational characteristics such as earnings, before and after tax profit, and so forth were analysed for both groups. Using such company characteristics, there was no statistical significance between responding and non-responding organisations. In addition, statistical analysis was carried out to compare those organisations whose executives responded early versus those who were late. Again, no significant differences emerged.

Sample Characteristics. With regard to organisational titles of the responding executives, $31 \%$ were CEOs or managing directors, $40 \%$ were managers, and 38\% were directors (or Vice Presidents) of finance or marketing. The variety of respondent titles indicated that on occasion, the questionnaire was passed on by the target recipient to another high ranking manager. On average, the responding organisational Elites were 44 years old and had 14 years of experience in their industry. They reportedly spent an average of six hours per week reading about developments concerning the external environment and seven hours per week discussing these trends with colleagues. This stated level of time commitment suggests a genuine awareness and appreciation of the importance of the external environment by the participating organisational elites.

Survey Items. The items included on the questionnaire were the result of an extensive literature search which was undertaken to ascertain the current views of various academic specialists and social commentators with regard to the future of the Australian business environment. The questionnaire was partially based upon the 
instrument used in the previous survey (Laczniak et al, 1989). However, it was substantially amended with various items which are seen as relevant to important current concerns regarding the external environment facing Australian business. In total, the questionnaire included over 300 items. The survey instrument itself was separated into three broad categories with batteries of questions focussing on the external environment, possible competitive strategies, and expected organisational performance levels. The environmental questions were classified into those which pertained to the Australian environment specifically and those which are relevant to the broader world environment. The external environment was divided into technological, political, social, ecological and world sub-environments. The strategy questions dealt with general competitive strategy and were further categorised according to the classic 4 P's of marketing: product strategy, pricing, promotion and distribution. The final section of the questionnaire contained inquiries about the expected financial performance of the organisation in the light of the forecasts that were being projected. Various demographic and organisational information was also gathered. A draft of the questionnaire was pretested with 21 Australian managers and subsequently revised.

Item Measures. Because of length considerations, the mail survey technique does not allow for a detailed explanation for each response given. Thus, the essential value of the information collected lies in the examination of the trends within each of the sets of questions. For each possible environmental trend, six response categories were possible ranging from $0 \%$ to $100 \%$ (at intervals of $20 \%$ ) with 0 representing no likelihood of occurrence and 100 representing a very high probability of occurrence. Thus, a manager might be asked, "What is the likelihood that Australia will face typical inflation rates of over $10 \%$ per year by the year 2000 " and the response options would consist of a $0 \%, 20 \%, 40 \%, 60 \%, 80 \%$ or $100 \%$ likelihood. For each of the items discussed, a mean likelihood $(\mathrm{ML})$ number representing the aggregate response of the expert sample is provided. In addition, dispersion measures are also given for each forecast. Thus, for each possible trend, three measures are reported. The mean likelihood (ML) measure represents the average probability assigned by the experts to each prediction. Lower quartile (LQ) and upper quartile (UQ) measures represent probability estimates and provide an indication of the dispersion of predictions which were 
generated. If the gaps between the LQ and UQ figure provided are relatively narrow, hen there is a reasonable amount of consensus about the prediction among the sample. In addition, for each set of questions dealing with the external environment (for example, the political environment), a two-point impact (IMP) index was computed. Here the respondents indicated whether each item was likely to have a high or low impact on their organisation. This measure is independent from the ML reported for each trend. Conceivably, a trend which is very likely to occur may have a low impact on the organisation and those trends with a low probability of occurrence could have a high potential impact. Thus, it should be noted that the probability of occurrence (ML) and the level of impact (IMP) would not necessarily be correlated.

\section{The External Business Environment Of Australia 2000}

\section{World Ecology In 2000}

We begin our discussion of the external environment with a series of issues that are likely to influence not only Australian businesses, but all global operations by the year 2000. These issues deal with possible events in the international ecological environment. As Edgar Wollard, the Chairman of DuPont stated in May of 1989: "In the future we [industry] will have to be seen as all one color. And that color had better be green" (Marcil, 1990). Nine ecological issues which could possibly exert substantial influence on Australian business organisations in the coming years were identified. The full set of issues is shown in Table 1. (Table 1 omitted) The ecological trend which garnered the highest average probability of occurrence was that there would be increased global pollution. That statement received a mean likelihood (ML) score of $76 \%$. This means that the average respondent said there is a $76 \%$ probability that this trend would be occurring in 2000. A side effect of this trend is that nations are increasingly intertwined in ecological terms. One nation's pollution of the ocean or air affects the economic activities of another. The political tensions between the United States and Canada over acid rain caused by American generated air pollution is a testimony to this kind of controversy.

Asia Pacific Journal of Management, Vol 11, No. 1 (April 1994): pg. 67-90. DOI. This article is @ Springer and permission has been granted for this version to appear in e-Publications@Marquette. Springer does not grant permission for this article to be further copied/distributed or hosted elsewhere without the express permission from Springer. 
Other world ecological trend statements with ascribed high probabilities were:

- that world population would continue to expand rapidly causing famine in Third World countries and social pressures elsewhere $(M L=66 \%)$;

- that there would be increasing international pressure, including sanctions, to influence environmental policies in certain countries ( $M L=56 \%)$; and

- that producers and consumers would accept higher costs in order to protect the environment $(M L=56 \%)$.

As referred to earlier, the executives were also asked not only to assess the mean likelihood of particular trends occurring, but also to state the impact of those trends on their particular companies. The "increased global pollution" statement which had the highest mean likelihood also had one of the highest likely impact ratings (IMP) of $43 \%$ (see Table 1). However, the next two statements concerning world population growth and increasing international pressure to influence environmental policy did not have particularly high impact ratings perhaps indicating that while these were important political and public policy questions, they would not translate immediately into major influences on most Australian organisations. One statement which had a relatively low mean likelihood score $(\mathrm{ML}=40 \%)$, namely that "worldwide shortages of oil will occur", had a relatively high impact rating of $41 \%$. This suggests that while the likelihood of shortages of oil only had a moderate probability of occurring, if it happened, the executives felt that it would have important ramifications for their operations. This result suggests, among other things, that executives should prepare contingency plans based on the possible occurrence of oil shortages.

The other trends scored by executives in this ecology section all had relatively low mean likelihoods and impact ratings (please see Table 1). One final perplexing observation here, particularly when compared with the study that was carried out five years ago (Laczniak et al, 1989), is that the organisational Elites did not see a high likelihood of the much discussed "greenhouse effect" being a major influence (a mean likelihood of only 34\%). The current ML reflects an estimated probability of occurrence of $58 \%$, a drop of $24 \%$ when compared with 1986 estimates. The oddity of this response is that the

Asia Pacific Journal of Management, Vol 11, No. 1 (April 1994): pg. 67-90. DOI. This article is @ Springer and permission has been granted for this version to appear in e-Publications@Marquette. Springer does not grant permission for this article to be further copied/distributed or hosted elsewhere without the express permission from Springer. 
greenhouse effect (which results from a reduction in the ozone layer) seems to be receiving increased scientific attention and scrutiny. This finding is, therefore, disturbing since this group of highly influential executives perceive this event as less likely to occur despite the evidence that the problem appears to be getting more serious. An implication for environmental lobbyists is that this particular group needs to be targeted and persuaded of the gravity of the problem much more effectively.

\section{The World Economy In 2000}

The sample of organisational Elites was next given a list of 15 possible trends concerning world economic events. A full listing of items is shown in Table 2. (Table 2 omitted) Perhaps the first thing that should be said is that the Australian executives rejected many of the worst case scenarios that were suggested by the statements concerning the world economy. For example, a $40 \%$ or less probability was given to statements which suggested worldwide political and financial instability, inflation rates exceeding $15 \%$ in most developed countries, a worldwide economic depression, and an international banking crisis caused by loan defaults. The item with the highest rating of probability of occurrence, came from the statement that large corporations will focus heavily on controlling labour costs with special emphasis on automation, computers and robotics. This statement garnered a mean likelihood score of $74 \%$. In addition, it had the highest estimated impact score upon corporate operations (IMP = $77 \%$ ). Another issue which captured widespread support was the notion that "worldwide sourcing for materials and components will increasingly gravitate to low cost provider nations". This statement had an ML of $69 \%$ and a relatively high IMP rating of $53 \%$. Obviously, the statement implied that a greater percentage of resources bought outside of Australia was a distinct possibility. Another economic item receiving strong support in terms of probability of occurrence (ML = $62 \%$ ) was that the "standard of living between developed and lessdeveloped nations would continue to widen." However, the executives felt that the impact of such an occurrence upon the typical Australian corporation would be relatively low (IMP = 19\%). Similarly, the statement that "economic systems around the world will become increasingly alike evolving into a capitalistic/socialistic hybrid" received

Asia Pacific Journal of Management, Vol 11, No. 1 (April 1994): pg. 67-90. DOI. This article is @ Springer and permission has been granted for this version to appear in e-Publications@Marquette. Springer does not grant permission for this article to be further copied/distributed or hosted elsewhere without the express permission from Springer. 
substantial support $(\mathrm{ML}=60 \%)$. However while these events might probably occur and might have an important influence on government foreign policies (recent events in Eastern Europe substantiate this) the overall impact on individual Australian corporations was felt to be relatively low $(\mathrm{IMP}=35 \%)$.

\section{Technology In 2000}

The expert sample provided their responses to eleven possible developments in the realm of technology. Many of the items selected have been suggested in previous writings as being important for Australia. Included here were questions dealing with the advancement of telecommunications, the automation of manufacturing, robotics, space projects, and the development of increasingly inexpensive computer systems. It is notable that eight of the items received a mean likelihood score in excess of $60 \%$. In addition, five of the items captured impact ratings which exceeded $74 \%$.

Table 3 summarises the executive opinions in terms of mean likelihood and impacts with regard to the technological trends investigated. (Table 3 omitted) Many of the most expected trend items related to the computer and telecommunications industry. Two factors which captured occurrence probabilities of above $80 \%$. These involved the development of increasingly powerful and inexpensive microcomputers that will make possible highly comprehensive and interlocking data banks ( $\mathrm{ML}=84 \%$ ) and the prediction is that the telecommunications/information and electronics industries will continue their ascendance $(M L=83 \%)$. Similarly, there was strong agreement with the statements that " $80 \%$ of individuals under 30 in developed countries will be computer competent" ( $M L=74 \%$ ), and that "innovative software will accelerate the trend towards reducing the levels of middle management" ( $M L=72 \%)$. Related to this last point, a mean likelihood score of $69 \%$ was also recorded by the statement that "the development of interlocking computer systems and data bases will provide managers with information to improve their productivity by $10 \% "$.

The significance of these technological expectations cannot be overstated as technology becomes a main source of solutions to deal with some of the problems that are likely to be uncovered in other

Asia Pacific Journal of Management, Vol 11, No. 1 (April 1994): pg. 67-90. DOI. This article is (C) Springer and permission has been granted for this version to appear in e-Publications@Marquette. Springer does not grant permission for this article to be further copied/distributed or hosted elsewhere without the express permission from Springer. 
areas of the external environment. Technology also represents a key mechanism by which organisations hope to attain a competitive advantage. Certainly, emerging service organisations with their activities directed toward international communications, private satellite networks, cellular telephone systems and telex, facsimile and electronic funds transfer are testimony to the vitality and centrality of such developments.

Two additional questions which relate to the utilisation of computer technology in manufacturing also displayed high probability and impact levels. The Australian business leaders generally agree that "the majority of manufacturing facilities in developed countries will have moved to significantly greater automation via computerised machine tools, robotic systems and CAD/CAM, and advance electronic manufacturing systems" ( $M L=74 \%)$. Such developments will clearly require workers with higher education and better training and possibly engender a labour shortage of qualified workers $(M L=61 \%)$.

Interestingly, the $\mathrm{ML}$ of automation in manufacturing has significantly increased to the current 61 level from a $21 \%$ mean likelihood found in a similar survey of Australian executives five years ago (Laczniak, et al, 1989).

Importantly, the organisational elites recognise the social implications that such advancement of technology may exert on some businesses. For example, they attribute a high probability to a prevailing climate of social and ethical problems caused by advancing technology $(M L=59 \%)$. It is also believed that these ethical considerations will have at least a moderate impact (44\%) on most organisations.

Somewhat surprisingly, the executives did not foresee a greater than $50 \%$ probability that space missions would provide a major economic boost to research and development in corporations with high technology operations ( $M L=46 \%$ ). This may be an indication that the managers simply felt that Australia was lagging behind the rest of the world in this area. The projection did not bode well for the Cape York peninsula initiative. Some Australians hope that this area could be commercially developed into a space port and possibly draw capital from the United States, Russia, and the European Space Consortium. However, given the break-up of the former Soviet Union and the

Asia Pacific Journal of Management, Vol 11, No. 1 (April 1994): pg. 67-90. DOI. This article is @ Springer and permission has been granted for this version to appear in e-Publications@Marquette. Springer does not grant permission for this article to be further copied/distributed or hosted elsewhere without the express permission from Springer. 
domestic problems facing the European community and the United States, such cash intensive economic developments may be fairly far off and the pessimistic assessment provided by Australian executives may be right on target.

Finally, we mention the skeptical response by the Australian organisational Elites to the question centred on retailing that "25\% of retail sales will occur via home computer terminals" ( $M L=46 \%)$. This reply extends the evidence from past research (Laczniak et al, 1989) that consumers are actually more reluctant to embrace the concept of home shopping than many other prognosticators have forecast.

\section{The Australian Social Environment In 2000}

There are dozens of issues dealing with the Australian social environment which could have been the focus of our survey. Population trends in particular have garnered substantial comment in recent years as the future population of Australia, particularly as it is affected by immigration policy, has become a front burner topic in recent years (IBIS, 1999) Our survey asked the respondents to react to ten social trends which, at least on the surface, could have major ramifications for Australian business. Table 4 summarises these trends along with the reaction of the expert sample in terms of their probability of occurrence and impact. (Table 4 omitted) Most noteworthy among the social trends in Table 4 perceived as "likely" by the Australian managers, is that three of the top four items (ranked in order of likelihood of occurrence [ML]) all have the common theme of education at their root. The social trend with the highest probability of occurrence had to do with Australian high school students having to be prepared for multiple job changes and/or careers during their lifetimes $(\mathrm{ML}=73 \%)$. Consistent with this, the respondents also projected that "life long continuing education requirements for management will require company commitment of at least twelve days per year toward this effort" ( $M L=64 \%)$. And providing a backdrop for both of these developments "the quality of public education at the primary, secondary, and tertiary levels will be a major concern" received an ML $=70 \%$. Simply stated, the Australian business leaders project education, both in its basic form and as manifested in continued training for the workplace, as undeniable influences in the future of

Asia Pacific Journal of Management, Vol 11, No. 1 (April 1994): pg. 67-90. DOI. This article is (C) Springer and permission has been granted for this version to appear in e-Publications@Marquette. Springer does not grant permission for this article to be further copied/distributed or hosted elsewhere without the express permission from Springer. 
Australian organisations. All of this is relevant to the ongoing debate about a national curriculum to standardise education in Australia and the need for better and more highly qualified mathematics and science teachers in Australia (Crisp, 1989). Based on these prognostications, it appears that the Australian executives recognise a changing pattern in adult working life from the preceding generation when individuals often stayed in the same employment for many years. It seems clear that tomorrow's workforce will need to be more flexible and better trained in order to adapt to various employment situations. While the expert sample was not as supportive of the view that "the Australian workforce will become increasingly stratified into two tiers: the technological elite and the more common underclass of relatively low paid clericals and service workers" (ML $=51 \%$ ), this view of a stratified workforce with polarised income has been expressed as a possibility for the Australian environment in previously published industry reports (IBIS, 1989).

Two other social trend items whose mean likelihood scores were in excess of $50 \%$ and which had impact scores exceeding $55 \%$ also had to do with the future Australian working force. In one case, it was perceived that company programmes providing on-site child care, flexible working hours, maternity and sick leave for children's illnesses will be more pervasive $(M L=56 \%)$. The other item had to do with the Australian workforce becoming less interested in job performance and more interested in job satisfaction $(M L=52 \%)$. The former development obviously has major cost implications for Australian business, while the latter raises critical issues of productivity at a time when Australian competitiveness is being internationally challenged as never before.

This issue of job satisfaction versus productivity is one that has caused heart-wrenching self-examination on the part of Australian society. It has been widely acknowledged in many writings that much of the traditional "work ethic" has vanished from Australia. A prominent theme to emerge regularly in cultural self-analysis among Australians has been the proclivity of labour working less but attempting to get more pay and benefits. To some extent, unions have been blamed for this attitude but more generally such values have been attributed to the "she'll be right" culture of Australia (Liberal Party of Australia, 1991). Obviously, factors such as holiday pay 
loadings, the nine-day fortnight, flexitime and a host of other potentially self-indulgent work practices which are perceived as inherent to the deteriorating work ethic must be addressed if Australia is to recover its position in the world economy (see Australian Institute of Management, 1990).

\section{Australian Political Environment In The Year 2000}

The Australian political environment was the next topic for examination by the executives. The 14 items chosen for response had a heavy emphasis on political trends that could conceivably affect general economic conditions and business operations. Certainly one of the most widely discussed aspects of Australia's environment in recent years has been its competitive standing in the world economy. Many prominent business leaders have expressed dissatisfaction with Australian political/industrial policy and the direction of Australia in terms of its strength as a player in the world economic marketplace. For example, in 1991 eight top Australian executives produced a document entitled "An Expression of Deep Concern" (Ralph, 1991). This report took the form of a statement of concern and a ten-point action programme. Significantly, it opened with the line "we are deeply concerned about Australia's long-run economic condition and the threat this poses to our community welfare" (Ralph, 1991). Recent economic forums have stressed the deterioration of the business environment in Australia and have included lengthy discussions about factors such as reduced worker productivity, high foreign debt, low savings and investment rates, high infrastructure costs and major political and bureaucratic impediments to economic activity. Business seminars generated by best selling books such as The Comparative Advantage of Nations (Porter, 1990), have raised questions about the degree of protectionism in Australia and contend that a nation cannot be globally competitive unless its own industries are exposed to the winds of economic competition. Interestingly, three survey items had to do with the expectancy of a greater degree of government regulation of business (see items seven, eight, and nine in Table 5). (Table 5 omitted) In general, the respondent group of top Australian executives are somewhat ambivalent about the amount of future regulation which the Australian business environment might experience in the next ten years. The mean likelihood scores for these

Asia Pacific Journal of Management, Vol 11, No. 1 (April 1994): pg. 67-90. DOI. This article is @ Springer and permission has been granted for this version to appear in e-Publications@Marquette. Springer does not grant permission for this article to be further copied/distributed or hosted elsewhere without the express permission from Springer. 
items seem to cluster around $50 \%$ meaning that there is some uncertainty as to the specific direction of government regulation. Perhaps this reflected uncertainty concerning which political party would hold the majority in the coming years. One item dealing with the regulation of bank practices seems to suggest that it was slightly more likely than not that increasing regulation in this area would be implemented $(\mathrm{ML}=53 \%)$. On the other hand, there seems to be relatively low likelihood ( $M L=42 \%$ ) that there would be legislation which would formally limit the extent of government involvement in private business activities.

However, one form of government intervention that did generate substantial support had to do with the possibility that "Australia adopts an industrial policy whereby the federal government assists key industries to be world competitive" (ML $=55 \%)$. In addition, it was believed by the expert sample that if this prediction came to pass it would have a substantial impact (60\%) upon Australian business organisations. The direction that such industrial policy formulation and industry targeting would take is a matter of speculation although some may read it as an encouraging sign that this would be the first phase in restructuring the Australian industrial sector. Certainly, there has been much discussion about the sustainable competitive advantages held by the Australian resources industry. For example, the mining of raw materials is a pinnacle of technology in Australia and offers excellent opportunities for many domestic organisations to develop further exports abroad. On the other hand, Australia's competitive advantage in areas involving minerals and natural resources is not backed up by a cluster of supporting industry services and infrastructures concerned with such operations. Various experts (for example, Gottliebsen, 1991) have speculated that the biggest rewards during the 1990s will go to those countries that have processing plants rather than those who are simply producers of bulk commodities. The conventional business wisdom seems to be that Australian companies have the ability to add much value to minerals and raw materials as well as exporting them in their unfinished state (Australian Institute of Management, 1990). However, there is also a belief which was expressed in a 1989 report by the Australian Science and Technology Council that it will be difficult for Australia to achieve significant compositional change in its industrial base by moving toward high technology processing. In the end, the 
Australian Science and Technology Council considers a government policy focussing on increasing current exports as the most feasible government option in the short-run and this may be the specific direction according to which this trend unfolds.

Other leading authorities (McKanna, 1990) are suggesting that the federal government is already targeting agriculture as a prime area for value added export income. Their recommendation is that this export base be broadened to include additional processed foods, processed hides and skins, the development of cotton and various other agricultural and technology exports. Perhaps if Australia chooses carefully (see for example, Korporaal, 1989), certain key industries can be incrementally developed (eg, the export of high quality, high fashion woollen clothing).

The political environment item receiving the highest probability of happening was concerned with substantially increased environmental regulation by the federal government. This item received a $\mathrm{ML}$ score of $78 \%$ and one of the highest impact ratings (58\%) (See Table 5). Certainly, this declaration by Australian executives concerning the importance of being mindful to environmental concerns is consistent with the writings of a number of experts as well as other data in this survey. For example, Clark (1990) has warned that business activities which interfere with environmental concerns will suffer increasing scrutiny from a broad-based community including such publicity generating organisations as Greenpeace. Some of this debate might culminate in environmental litigation against business organisations from members of the public and other stakeholders seeking recompense for alleged environmental damage.

The majority of expert business respondents supported the likelihood that "Japanese and other foreign ownership of Australian real estate and financial securities will further complicate the ability to control the Australian economy". (ML 54\%) However, it is also important to note that the business leaders did not generally foresee $(M L=35 \%)$ severe outcomes such as political measures which would restrict foreign investment in Australia. The extent of the involvement of the Japanese in the Australian economy has been much discussed and was fueled by the Multi-Functional Polis (MFP) initiative during the 1980s. This initiative and others called for long-term leasing

Asia Pacific Journal of Management, Vol 11, No. 1 (April 1994): pg. 67-90. DOI. This article is (C) Springer and permission has been granted for this version to appear in e-Publications@Marquette. Springer does not grant permission for this article to be further copied/distributed or hosted elsewhere without the express permission from Springer. 
arrangements with foreign investors rather than outright sales (Liberal Party of Australia 1991). As in the United States, various parties have raised concerns about the possibility of Japanese hegemony over Australian economic affairs (Korporaal, 1990). However, judging from the response of our expert sample it appears that the Australian executives understand the value of foreign investment including the inflow of new technology and superior market knowledge. It is interesting to note that a similar poll of Australian executives taken five years earlier (Laczniak et al, 1989) projected by a much higher mean likelihood ( $M L=69 \%$ ) that there would be restrictions passed with regard to foreign investment. Such restrictions did not materialise in Australia during the period 1987-1992.

Finally, it should be noted that the expert sample projected that the elderly (65 and over) would accrue increased political power in the coming years $(\mathrm{ML}=64 \%)$, but that they doubted that "labor unions will increase in political power" $(M L=33 \%)$. With regard to the elderly gaining power, simple demographics indicate that the population will be ageing although this trend has been offset somewhat by immigration. Thus, it is not surprising to expect that the political clout of older citizens in Australia will be enhanced. However, on balance, the business executives felt that this development (if it happened) would have minimal impact on the operation of Australian organisations (IMP $=24 \%$ ). This seems curious given the potential political influence of enhanced elderly power upon superannuation schemes as well as taxation. Meanwhile, the feeling that union power would not increase dramatically may be tempered by the fact that at present it remains relatively strong. Certainly, many social critics had cited the Mark VI accord agreement giving unions additional leverage over superannuation funds as evidence that the union movement in Australia has been strengthened in recent years.

\section{Economic/Social/Political Developments In Australia 2000}

The final topic dealing with the external environment contained a series of broad-based statements reflecting possible shifts in the economic, social and political dimensions of Australian business life. Fifteen specific topics were selected for inclusion in the questionnaire

Asia Pacific Journal of Management, Vol 11, No. 1 (April 1994): pg. 67-90. DOI. This article is @ Springer and permission has been granted for this version to appear in e-Publications@Marquette. Springer does not grant permission for this article to be further copied/distributed or hosted elsewhere without the express permission from Springer. 
based largely upon their prominence in the business press and the level of debate that they generated. Among the issues addressed were immigration policies, aboriginal concerns and the possibility of a consumption tax (see Table 6). (Table 6 omitted)

The highest ranking statements in this section in terms of predicted likelihood of outcome represent sectors of opportunity for Australian business. Particularly notable was the reaction of the respondents that tourism would make a major contribution ( $25 \%$ greater than 1990 levels) to the Australian economy $(\mathrm{ML}=72 \%)$. Certainly, tourism has been previously identified by many commentators as a possible growth sector for Australia, and the business managers affirmed this expectation. For example, the San Francisco based Pacific-Asia Travel Association (PASA) in a paper titled "Direction 2000" expected holiday travel to grow $163 \%$ in the next ten years in the Pacific Rim region (Browne, 1990). According to the report, this translates to 100 million passenger movements by the turn of the century. Other experts have concurred with this prediction (Davis, 1991). Australia certainly has a natural environment which ought to provide a natural magnet for tourists. Its unique flora and fauna, the unusual landscape, the comparatively high levels of public safety, the increasing numbers of elderly with resources from around the world who are willing to spend their leisure time travelling, may all contribute to this eventuality. However, the development of a potential "tourist boom" is one that would affect only a limited number of industries (IMP $=47 \%)$.

Another source of optimistic expectation among the sampled managers is that mining and processing of natural resources are predicted to be among the brightest sectors of the Australian economy $(\mathrm{ML}=70 \%)$. Currently, 690 of Australia's total exports of goods and services are primary products (raw materials and agriculture). Coal, aluminum and iron ore will continue to remain the backbone of the mining sector. However, various authorities (Korporaal 1989) predict the increased importance of uranium as an energy source because of the polluting dimensions of coal. Our expert sample of business executives was more uncertain about the role of agriculture in Australia's future. With regard to the statement "the importance of agriculture will increase significantly as exports are expanded to accommodate developing country needs" they assessed only a ML of 
$51 \%$. Perhaps this ambivalent forecast can be attributed to the fact that agriculture's share in world trade has declined steadily over the past 40 years and that such a decline will not be offset by the expected reduction of world tariffs.

Another potential area of economic opportunity highlighted by the executive forecasts had to do with the formation of international trading blocs. There has been much speculation by the experts (Woodward, 1989; IBIS, 1989; Stutchbury, 1990; and Holloway et al, 1991) on the eventuality of trading blocks. The high ranking Australian managers polled in this study suggested that there is a high probability that the anticipated developments of European integration in 1992 and beyond will force Australia to move further away from Europe in both economic and cultural/social terms and towards Asia. A statement reflecting this sentiment had a strong mean likelihood $(M L=71 \%)$ (See Table 6). Also receiving a moderately high probability of occurrence were two other statements related to trading block or trading block tendencies.

- Australia will become part of the ASEAN trading bloc (ML $=$ $53 \%)$.

- The economic allegiance of Australia will continue to shift toward Japan (50\% greater than 1990 levels) with the implementation of projects such as the MFP and similar joint ventures $(M L=57 \%)$.

While neither of these statements received overwhelming support, neither are they necessarily independent events. In the next decade, Australia could continue to increase its ties with the ASEAN trading block while at the same time strengthening its ties to Japan. Whether Japan would "throw in" with this group is an open question. The responding experts also reacted to the following related statement: "The world is likely to separate into three major well developed trading blocks (Europe, America and Asia) with the rest of the underdeveloped world being shut out and doomed to remain in poverty" ( $M L=55 \%)$. All these projections taken together seem to suggest that most executives sense that a greater integration of Australia with Asia seems to be inevitable by 2000 . Precisely what the manifestation of that integration will be is open to speculation. In this vein, it is interesting, for example, that the executives did not allocate

Asia Pacific Journal of Management, Vol 11, No. 1 (April 1994): pg. 67-90. DOI. This article is @ Springer and permission has been granted for this version to appear in e-Publications@Marquette. Springer does not grant permission for this article to be further copied/distributed or hosted elsewhere without the express permission from Springer. 
a greater than $50 \%$ to the possibility that a compulsory Asian language, possibly Japanese, would be introduced into the Australian primary and secondary school curriculum (see Statement 13, Table 6).

Some of the statements dealing with social/political trends which did not receive high ML's of occurrence were as interesting as those that did. For example, immigration policy which has stirred major debate across Australia over the past decade or longer is not thought to be a relatively strong political issue (Statement 12, Table 6). Perhaps executives are more likely to take the position of many economic and urban planners (see Gill, 1990) which holds increased immigration to be non-threatening. Similarly, aboriginal land rights and programmes were not seen to be a predominant issue in the year 2000 nor a costly federal government line item ( $M L=47 \%)$. The restrictions wrought by the green movement are not seen as damaging the ability of Australia to harvest its national resources to the extent that some environmentalists would expect. Ironically, it was recent environment concerns that slowed down some major mining developments (eg, the 1991 decision to ban mining at Coronation Hill and a mineral reserve adjacent to the Kakadu National Park) and caused heated debate at the federal level.

\section{Environmental Perceptions Determine Strategy}

A scan of the external environment, no matter how accurate or thought provoking, only has meaning for the individual organisation in terms of how it affects its competitive environment and the selection of its particular competitive strategies. In an attempt to capture some of the linkage between how executives viewed the external environment and how they thought these trends would then affect their competitive situation and the specific strategies chosen, the high level Australian managers reacted to two batteries of questions dealing with key aspects of the competitive environment. The first battery of questions (49 items) had to do with competition at home and abroad. These items were selected and organised based upon the logic of strategist Michael Porter (1980). Porter in his pathbreaking book on strategy (1980) perceived the nature of competition as being driven by five forces. These forces were concerned with existing rivalry in addition to supplier and buyer factors as well as the threat of potential

Asia Pacific Journal of Management, Vol 11, No. 1 (April 1994): pg. 67-90. DOI. This article is @ Springer and permission has been granted for this version to appear in e-Publications@Marquette. Springer does not grant permission for this article to be further copied/distributed or hosted elsewhere without the express permission from Springer. 
entrants and substitute products or services. Essentially, the confluence of the forces determine the ultimate profit potential of a particular industry (where profit was measured in terms of long run ROI). In the end, Porter felt that organisations within an industry had to choose from three generic strategies: cost leadership, differentiation or focus in order to attain success in competitive environments. Organisations that select one (or more) of these strategies appropriately and execute it well will be successful. Companies who are "stuck in the middle" and cannot effectively execute one of these strategies will perform poorly from a financial standpoint.(1) As in previous sections, the expert sample of executives was asked to estimate the mean likelihood (ML) that their organisation would engage in a particular practice, given the environment they expected to face in the year 2000.

\section{International Strategy And Australian Organisations In 2000}

With regard to foreign markets seed, there was a strong feeling among the managers polled that the number of markets in which Australian organisations would be involved would increase (ML = $62 \%)$. There was also a strong expectation that the foreign markets served would become more highly segmented $(\mathrm{ML}=58 \%)$ perhaps indicating that many Australian organisations would be following a differentiated or niche (ie, focus) strategy. Sometimes the items that receive the lowest level of projected occurrence provide an interesting story as well. In this case, there seems to be little enthusiasm on the part of the Australian managers that foreign market expansion by Australian firms would emphasize either the consolidated western European market or the Commonwealth of Independent States (CIS) and its former eastern European affiliates. Both these possibilities received mean likelihoods of less than 30\%. Thus, by implication (as well as the direct evidence discussed earlier concerning Australian executive feelings concerning trading blocks) it seems the majority of respondents are predicting that Australia will be forming closer ties with Asia and other geographically approximate markets (eg, the South Pacific) rather than looking to Europe.

Asia Pacific Journal of Management, Vol 11, No. 1 (April 1994): pg. 67-90. DOI. This article is @ Springer and permission has been granted for this version to appear in e-Publications@Marquette. Springer does not grant permission for this article to be further copied/distributed or hosted elsewhere without the express permission from Springer. 
With regard to the nature of competitive intensity with foreign rivals, the Australian executives expected such competition to be fierce as 2000 approached. Mean likelihood scores in excess of $63 \%$ were garnered by the following statements:

- Our international competitors will be aggressively fighting to maintain or increase their share of the market ( $\mathrm{ML}=70 \%)$.

- International competitive rivalry will have increased significantly in our industry $(M L=66 \%)$.

- Foreign price competition will be intense $(M L=63.2 \%)$.

In addition, regarding substitute products coming from foreign competitors, the general expectation was that these will increase competition with firms that produce such products $(M L=59 \%)$. Interestingly, however, concerning foreign suppliers (raw materials, components, and other industry inputs), there seems to be a relatively low probability that this dimension of competition would increase significantly, at least for the companies polled.

With regard to foreign customers, there seems to be a degree of optimism among the Australian managers. For example, relatively low probabilities (ML's $=36 \%$ ) were assigned to the eventualities that the number of foreign customers of Australian firms would decline or that foreign customers would have superior negotiating power in dealing with Australian businesses.

Finally in terms of foreign market entry, the business leaders assigned joint ventures as the most likely method of entering into foreign markets $(M L=60 \%)$. In contrast, the use of direct ownership to enter foreign markets was given a $\mathrm{ML}$ of only $42 \%$ indicating that, in general, Australian organisations would prefer to share the risk (and profit potential) of entering new markets as opposed to entering them on their own.

\section{Australian Competitive Strategy}

As noted above, the executives were also provided with over two dozen statements of competitive strategy that embody possible strategic directions for their organisation as they approach 2000 . What is most significant about the reactions of the Australian organisational

Asia Pacific Journal of Management, Vol 11, No. 1 (April 1994): pg. 67-90. DOI. This article is (C) Springer and permission has been granted for this version to appear in e-Publications@Marquette. Springer does not grant permission for this article to be further copied/distributed or hosted elsewhere without the express permission from Springer. 
elites is the general pattern of response. First, an extremely high probability of occurrence ( $M L=84 \%$ ) was assigned to the assertion that Australian organisations will always attempt to operate in an ethical, socially responsible fashion. This imperative no doubt was a product of the many scandals of the late 1980s which racked Australian organisations and caused the Australian business community to be viewed with great scepticism in international financial circles. The widely realised economic and psychological trauma associated with these breaches of ethical conduct have seemingly resulted in the strong imperative that Australian organisations have, in not repeating these ultimately unfortunate transgressions.

Equally noteworthy among the pattern of responses is the heavy concentration around strategic directions that are customer focussed. Note the following with regard to future intentions of Australian business leaders:

- Offer better/more responsive service than competitors to customers $(\mathrm{ML}=77 \%)$.

- Achieve or maintain leadership in overall product or service quality $(\mathrm{ML}=75 \%)$.

- Achieve and maintain a strong orientation to customer needs and problems that pervade all parts of the organisation (ML $=74 \%)$.

- Achieve and maintain a high visibility/awareness among customers ( $M L=72 \%)$.

- Develop the closest possible relationship between the salesforce and the customers $(\mathrm{ML}=71 \%)$.

Again, what characterises all of these strategies is their concentration upon the customer in delivering superior quality and satisfaction. In seeking a common denominator for these strategies, one is left with the impression that they involve differentiation strategies as described by Porter. This is particularly true when one examines the specific competitive strategies which receive the relatively lowest expectation of occurrence. These tended to be strategies which were price or cost oriented--the generic alternative to differentiation. Consider the following:

- Offer prices at or below those of competitors $(M L=44 \%)$.

Asia Pacific Journal of Management, Vol 11, No. 1 (April 1994): pg. 67-90. DOI. This article is @ Springer and permission has been granted for this version to appear in e-Publications@Marquette. Springer does not grant permission for this article to be further copied/distributed or hosted elsewhere without the express permission from Springer. 
- Achieve the largest economies of scale in manufacturing (ML $=44 \%$ ).

- Achieve the lowest cost by extensive vertical integration (ML $=39 \%$ ).

Thus, looking for a common pattern among all of the competitive strategies, it appears that Australian managers expect that being a low cost competitor (again ala Porter) is far less likely than Australian organisations attaining a sustainable competitive advantage via the generation of quality, service and attention to key customers.

\section{Elements Of Marketing Strategy In 2000}

The set of tools that a firm uses to pursue its marketing objectives in a particular target market is often referred to as the marketing mix (Kotler, 1991). The marketing mix has historically been classified as including dimensions of product strategy, pricing, promotion and distribution (McCarthy and Perreault, 1990).

In this section of the survey, our sample of Australian managerial Elites was asked to estimate the likelihood (ML) that they would engage in specific marketing strategies as a result of the external and competitive environments that they perceived in evolving for their organisation by 2000. A series of over 50 items was posed to the executives (see Appendix) and organised around the elements of the marketing mix. Below, we briefly comment on strategies that the executives felt would most likely increase in importance in the coming decade.(2)

The category of marketing elements that received the highest level of expected future increase came from the product strategy group. The single most expected strategy option had to do with the notion that product quality would increase in importance ( $M L=80 \%)$. Three additional product related strategies including post sales service, new product research, and product planning research all received probability ratings of $70 \%$ or greater. This sample reaction conforms with the earlier study (Laczniak et al, 1989) where the product area was felt to be a primary sector of critical emphasis by Australian managers. Certainly these views are consistent with the earlier

Asia Pacific Journal of Management, Vol 11, No. 1 (April 1994): pg. 67-90. DOI. This article is (C) Springer and permission has been granted for this version to appear in e-Publications@Marquette. Springer does not grant permission for this article to be further copied/distributed or hosted elsewhere without the express permission from Springer. 
discussed finding that differentiation would be a prominent generic strategy among Australian companies.

With regard to promotional strategy, the specific item issue receiving the highest probability of occurrence was that "public relations, consumer affairs, and community relations" would increase in importance $(M L=68 \%)$. This belief in the relative future importance of public relations and community outreach efforts is consistent with some of the previous observations already made, especially the intention of Australian organisations to pay greater attention to customer needs as well as the absolute necessity of a high ethical posture in the light of the past scandals which have plagued Australian businesses.

With regard to the area of channels, the single tactical area selected for the greatest relative future emphasis had to do with the selection of channels of distribution ( $M L=63 \%)$. Compared with the last study of Australian executives (Laczniak et al, 1989), the current response levels represent a relatively greater emphasis on channel selection. During the previous poll of Australian executives, warehousing and inventory control received the greatest relative expected increase in distribution strategy. This time, while the ML for warehousing and inventory control attained a mean likelihood of 56\%, it was not nearly as relatively important among the possible distribution strategies as it had been five years earlier.

Finally, the various pricing strategies were examined. The pricing strategy which was accorded the highest projected emphasis had to do with "pricing according to what the market will bear" ( $\mathrm{ML}=$ $65 \%)$. This is similar to the results attained in the previous study of Australian executives. Also interesting in the general realm of pricing was the strong lack of support for an increased emphasis upon global pricing strategy which attained only a ML of $26 \%$.

\section{Conclusion}

As noted already, this survey of experts was composed of individuals who necessarily must think about the future by virtue of the positions they hold. Previous exercises along similar lines (Laczniak et al, 1989) generated predictions which accurately captured trends

Asia Pacific Journal of Management, Vol 11, No. 1 (April 1994): pg. 67-90. DOI. This article is (C) Springer and permission has been granted for this version to appear in e-Publications@Marquette. Springer does not grant permission for this article to be further copied/distributed or hosted elsewhere without the express permission from Springer. 
which subsequently assumed greater importance in Australia. Among these accurately projected external developments were forecasts by Australian business leaders about the growing importance of ecological concerns (eg, mining and the physical environment), deregulation (eg, banking and the airlines) as well as greater concerns for public education in Australia. But beyond the debatable notion of accurate prediction, another goal of equal prime importance of this exercise is simply to make clear the assumptions about the future under which many Australian managers are operating. For it is these assumptions that will be a heavy influence upon the business action and strategies which are implemented in the present as Australian business prepares to meet the future.

Highlighting the findings of this current scan of the Australian business environment 2000, we find the following:

First, a number of ecological trends are seen as likely to occur. For example, there is a high probability that there will be increased global pollution, population pressures in other nations that will continue to influence economic events and increased levels of environmental regulation worldwide. Interestingly, the "greenhouse effect" is assessed a relatively low probability of occurrence especially when compared with previous predictions.

Second, with regard to world economic trends, there seems to be a general acceptance on the part of the executives that the world will separate into regional alliances for the facilitation of world trade. It is more than likely that such developments will force Australia to move further away from Europe in both economic and cultural/social terms and toward Asia, perhaps resulting in alliance with the ASEAN trading block. On the other hand, the executives do not foresee the enactment of measures which will severely restrict foreign investment in Australia. Much of this will be influenced by the relatively high probability assigned to the trend that immigration will continue to change the character of Australian culture significantly, moving it from an Anglo-dominated society to one which is more psychologically integrated into Asia. For example, the recent 1992 decision by the Australian government to allow 20,000 Chinese students to remain in Australia indefinitely (because of political instability in China) is further evidence of such a development.

Asia Pacific Journal of Management, Vol 11, No. 1 (April 1994): pg. 67-90. DOI. This article is @ Springer and permission has been granted for this version to appear in e-Publications@Marquette. Springer does not grant permission for this article to be further copied/distributed or hosted elsewhere without the express permission from Springer. 
Third, technological advancement in various forms is seen as a potentially positive change agent. The Australian managers were supportive of the variety of forecasts concerning improvements or breakthroughs in technology involving areas such as microcomputers, telecommunications, automated manufacturing and information systems. The Australian business leaders ascribed a high probability to the statement that $80 \%$ of individuals under the age of 30 will be computer competent. Obviously, the training of future and current employees to adapt to the increasingly technological environment will be a critical future challenge for Australian businesses.

Fourth, the quality of education at all levels of Australian society (primary, secondary, and tertiary) continues to be a deep concern for the polled executives. Multiple job changes and careers will be the expectation of the next generation of Australians. This will require a high priority for continuing (management) education for university graduates and the opportunity for extended technical education for other members of the workforce.

Fifth, the workforce of the future will have an entirely different composition from many of today's workers, especially in their attitudes toward both work and leisure. Based on the literature review and managerial responses to this survey, company programmes involving on-site child care, flexible working hours, maternity leave and sick leave for child illnesses will be critical concerns for Australian organisations. Flexibility will be the key to an organisation developing an efficient and satisfying work environment.

Sixth, certain sectors of the economy were ascribed a particularly high likelihood of substantial growth. These included tourism as well as the mining and the processing of natural resources. In this vein, there was a relatively high probability ascribed to the position that Australia would adopt an industrial policy whereby the federal government would assist key industries to become world competitive.

Seventh, with regard to the strategy implications of the external environment perceived by Australian managers, the satisfaction of the customer with superior quality and service seem to be the dominant theme with many of these differentiating elements coming to fruition 
through the use of various forms of product strategy such as product innovation, quality enhancement and service delivery.

In conclusion, whether these forecasts materialise precisely as envisioned or not is less important than the hope that they serve as a stimulant to drive Australian managers to consider the future business environment and engage in the inherent contingency planning that such consideration necessarily involves.

\section{Footnotes}

1. A full listing of the items and scores that were part of "foreign market" considerations are available from the authors on request.

2. Again, a full listing of items and scores is available from the authors on request.

\section{References}

Aguilar, F J, (1967), Scanning the Business Environment, McMillan, New York. Australian Institute of Management, (1990), A view from the top--a qualitative exploration of the mind and mood of Australia's CEOs, Mackay Research Pty. Ltd, November.

Australian Science and Technology Council, (1989), The contribution of science and technology to Australia's balance of payments to the year 2000--The primary sector, Occasional Paper No 8, June.

Australia's Top 500 Companies, (1989/90), The Business Who's Who of Australia, Riddell Publishing Ltd., 3rd edition, Sydney.

Browne, D, (1990), Cape York tourism faces the hard sell, Australian Business, 5 September, 64-65.

Clark, D, (1990), Challenges to business--three big issues for this decade, Financial Review, 23 August, 31-32.

Crisp, L, (1989), The Dawkins revolution arrives, The Bulletin, 31 January, 78-85.

Davis, B, (1991), Service industries hold great potential, Australian Business, 31 July, 50-56.

Fisher, A B, (1990), Is long-range planning worth it? Fortune, 23 April, 137140.

Gill, M, (1990), Hawke announces probe into central issues of migrant debate, Financial Review, 15 November, 4.

Gottliebsen, R, (1991), Great opportunities, great danger, Business Review Weekly, 19 April, 46-49.

Asia Pacific Journal of Management, Vol 11, No. 1 (April 1994): pg. 67-90. DOI. This article is @ Springer and permission has been granted for this version to appear in e-Publications@Marquette. Springer does not grant permission for this article to be further copied/distributed or hosted elsewhere without the express permission from Springer. 
NOT THE PUBLISHED VERSION; this is the author's final, peer-reviewed manuscript. The published version may be accessed by following the link in the citation at the bottom of the page.

Holloway, N, Rowley, A, Islam, S and Vatikiotis, M, (1991), East Asian trade grouping at top of region's agenda: An insurance policy, Far East Economic Review, 25 July, 52-53.

IBIS, (1989), Australia tomorrow--an insight into strategic planning issues challenging Australian management, IBIS Information International, Ltd., September.

Jain S C, (1984), Environmental scanning in U.S. corporations, Long Range Planning Vol 17, 2, 177-128.

Klein, H E and Linneman, R E, (1984), Environmental assessment: An international study of corporate practice, Journal of Business Strategy Vol 2 No 4, 74-75.

Korporaal, G, (1989), Where the profits will be, The Bulletin, 31 January, 5456.

--(1990), Japan's super-rich target Australia, The Bulletin, 1 May, 38-46.

Kotler, P, (1991), Marketing Management--Analysis, Planning, Implementation and Control, 7th Edition, Prentice-Hall International Editions, New Jersey.

Laczniak, G R, Pecotich, A and Carroll, B, (1989), A tough future for Australian business? Long Range Planning Vol 22, 1, 48-60.

Liberal Party of Australia, (1991), Australians speak: A report on the concerns, hopes and aspirations of the Australian people, Australia 2000 Project.

Makridakis, S and Wheelwright, S C, (1987), The Handbook of Forecasting--A Manager's Guide, 2nd Edition, John Wiley and Sons, USA.

Marcil, A G, (1990), The boardroom goes green, Business India, 15 April, 117-118.

McCarthy, E J and Perrault, Jr W D, (1990), Basic Marketing, 10th Edition, Homewood, Irwin, IL.

McKanna, G, (1990), Extra processing could boost Australia's rural export profits, Financial Review, 21 February.

Porter, M E, (1980), Competitive Strategy: Techniques for Analysing Industries and Competitors, MacMillan Publishing Co. Inc., New York.

--(1990), The Competitive Advantage of Nations, The MacMillan Press, London.

Ralph, J T, (1991), Our Competitive Future--The Shape of a Competitive Australia, Business Council of Australia, Sydney, March. Published by Business Council of Australia.

Stutchbury, M, (1990), Walls come tumbling down, Financial Review, 17 September, 12.

Woodard, G, (1989), Australia in 2001: A South Pacific orphan? The Independent Monthly, October, 51-52.

Asia Pacific Journal of Management, Vol 11, No. 1 (April 1994): pg. 67-90. DOI. This article is (C) Springer and permission has been granted for this version to appear in e-Publications@Marquette. Springer does not grant permission for this article to be further copied/distributed or hosted elsewhere without the express permission from Springer. 
NOT THE PUBLISHED VERSION; this is the author's final, peer-reviewed manuscript. The published version may be accessed by following the link in the citation at the bottom of the page.

*Professor, Department of Marketing, Marquette University, Milwankee, WI 53233; Senior Lecturer and Honours Student, Department of Information Management and Marketing, University of Western Australia, Nedlands, Western Australia 6009. 